\title{
The process of developing an emotional nexus between the self and an uncanny geography: An autoethnography
}

\author{
Ceren Boğaç \\ Eastern Mediterranean University, Department of Architecture, Famagusta, North Cyprus, Via Mersin 10, Turkey
}

\section{A R T I C L E I N F O}

\section{Keywords:}

Place attachment

Autoethnography

Uncanny geography

Emotions

Varosha

\begin{abstract}
A B S T R A C T
In this paper, I aim to explore my nexus with a prohibited place and its emotional meaning, reflected over a 30year period. This exploration involves evocative autoethnography in which I discuss my process of bonding to a place. Varosha, a quarter originally built by the Greek Cypriots in Famagusta, Cyprus, was unwillingly abandoned by them after the island was fragmented in 1974. Since then, entry to this place has remained prohibited. My childhood and adolescent years were centered in this unusual geography. Varosha is known as a "ghost town" in international media, and yet, I would not define it as a specter, rather as an uncanny geography because I have experienced it as both a familiar and an unfamiliar place. In this paper, I have identified this bond as an "empathic place attachment." I believe that emotions evoked toward a prohibited place are a rare fabric of our personal geographies that provide a new assessment of the nexus between the self and place.
\end{abstract}

Preface

Famagusta is a coastal city in the northeastern region of Cyprus, an island divided into two based on the ethnic identity of its two main communities: the Turkish Cypriots in the North and the Greek Cypriots in the South, and Varosha, a quarter along the city's golden shores, was once the most vibrant center of tourism in the Mediterranean region during the 1960s. The island's de facto fragmentation, which continues today, has been traced to internal conflicts that brought both communities on the brink of war in 1974 and caused many people to relocate from north to south and vice versa. Many places became new residences for members of each community, depending on the communal majority. However, Varosha's destiny was different. Immediately after the conflicts ended in 1974, the Greek Cypriots-its original inhabitants-involuntarily abandoned the place. Closed off to the public with barbed wire fencing, a large portion of Varosha was placed under Turkish army control and the remaining under the United Nations-it became a symbol of the north-south conflict. In the beginning, people believed that Varosha was being kept as a bargaining chip for the bicommunal talks between the Greek and Turkish Cypriots on a possible reunification of the island. Now, after 45 years of being held hostage, Varosha has been depicted as a "ghost town" in international media.

This strange geography, once called "paradise" by the original inhabitants, has had a profound impact on my life-I see Varosha more as a post-apocalyptic landscape that has haunted me for over 30 years. I was born in Famagusta in 1979, five years after the island was divided, as a new generation of Turkish Cypriot. My father was a refugee from Larnaca, a town in the south of Cyprus, who was forced to leave his home and belongings, just like the Greek Cypriots who had to abandon Varosha. My father's family was settled in an abandoned house in Kato Varosha (the lower section of the town) that originally belonged to a Greek Cypriot family. The house was situated on a property considered equivalent to the home his family had left behind. I spent my childhood in that house, which was located along the periphery of Varosha, and over time, witnessed the houses across the border deteriorate, shrubs and trees conquer the pavement, and thousands of birds become the new inhabitants of almost every apartment block and hotel in the vicinity.

\section{Introduction}

There is a continuous yet irregular connection between emotions and places, which assists us in the construction and interpretation of the world around us. Consequently, during the last decade, there has been an increased interest in emotions within geographical contexts, ranging from landscapes to homelands and material to spectral. Various actors' experiences in places from their childhood (Cooper Marcus, 1992) to adulthood (Brown and Perkins, 1992) have been studied exclusively. Interactions, associations, sudden encounters, realizations, and above all, their creation and intensification have been identified as indicators contributing in the process of emotion generation toward a specific place (Seamon, 2014). In most of the studies, experience-in-place or

E-mail address: ceren.bogac@emu.edu.tr. 
characteristics of a place is defined as the main factor in developing emotional connections with an environment (Gustafson, 2001; Tuan, 1977); prohibited geographies, however, have been neglected from these discourses.

Conversely, a quarter century ago, Low and Altman (1992, p.6), asked, "What about attachments to places with which we have had direct experience versus places that we have only known about indirectly?" The answer to this question remains elusive since little research has been conducted to examine the process of people's emotions and connections toward a place they have limited access to or experiences in. One possible reason why the existing literature does not explore prohibited geographies could be the fact that conceptualizations of emotional engagement between the self and place are generally based on factors such as having control over the area (Brown, 1987), safety issues (Scannell and Gifford, 2014), and socio-cultural experiences (Von Wirth et al., 2016).

This paper concerns encounter and emotional engagement with a prohibited geography over a period of 30 years, a rarity vis-à-vis the existing literature. This delicate exploration has unsolved a personal ethnographic narrative of Varosha, which is a special case to being a prohibited place that is a cultural artifact and material memory of the ongoing conflict in Cyprus. Varosha evokes conflicting emotions those who have encountered the abandoned breakfast tables, furniture, cars, and other belongings left behind by the original inhabitants, and all still visible through the barbed wires. However, the entry restrictions and prohibitions against taping/recording in Varosha make it an exceptionally challenging geography to study.

As the title implies, I first present how an emotional nexus between people and places has been conceptualized in the literature. Next, I describe the theoretical framework I used to conduct my appraisal of the symbolic relationship developed with a prohibited place, and then, discuss the method I used to reproduce my past emotional-spatial experiences of Varosha over the past 30 years. Finally, in the fourth section the most evocative, I reconstruct and simulate my emotional journey toward this strange geography while making connections with existing theories.

My motivation for this paper is manifold. First, I believe that emotions toward prohibited places are a rare fabric of our distinctive personal geographies that provide new assessments of the nexus between the self and place. Therefore, I wanted to track how a prohibited geography might engender personal connective tissue capable of contributing to the existing discourse on place attachment. This is because neither the unusual landscape of Varosha, nor the authorized sociopolitical endeavor aimed at wiping out its existence from people's lives by declaring it a prohibited area has prevented me from developing an attachment to it.

In almost every study, feelings of those who were born and raised in the region after 1974 and their possible attachment to Varosha were not taken into consideration or analyzed. With this paper, as a member of a post-conflict generation, I want to explore the process of my emotional nexus with Varosha to achieve a wider personal, social, cultural, and spatial understanding of this prohibited place. With this, I also hope to contribute to the ongoing negotiations regarding its future by revealing the emotions for, and meaning of, this place for a Turkish Cypriot, which have been completely ignored in both the research conducted so far and the bicommunal talks. Devine-Wright (2014) highlighted the importance of studying the processes involved and importance of establishing a bond with a place over time; according to him, no research covering a period of more than 12 months has been conducted. With this paper, I also hope to contribute to the longitudinal research literature by providing insights into patterns of emotional engagement with a place over the course of 30 years.

\section{The emotional nexus between the self and place}

The concept of place has been a central subject for everyday life since the time of Greek philosophers Plato and Aristotle. Within his theories of existence and the process of becoming, Plato developed the concept of chora, which refers to a place in the process of becoming, and topos, which indicates an achieved place (Casey, 1997). Similarly, Aristotle set the concept of "place" at the center of his philosophy where every existing thing must be from somewhere, and hence, place always comes first (Casey, 1997). Since then, countless theories and philosophies related to place have been developed. For example, 20th-century philosopher Heidegger developed an inquiry emphasizing people's connection with a place. His conceptualization of "Dasein" (Heidegger, 1962), a German word meaning "being there" that can also be interpreted as "being-in-the-world" or "being in place," refers to a person's never-ending experience with a place. Since place has always been at the heart of philosophical inquiry pertaining to human existence, Casey's dictum (1993, p. 313) "to be is to be in place", represents possibly one of the most powerful and essential motivational perspectives to understanding the importance of studying the nexus between the self and place.

Emotional engagements form the basis of the meaning-making process between the self and place (Bondi, 2005). Emotions contain a complex pattern of reactions toward a place that involves feelings, which may also act as the mental aspect of an experience. Hence, emotions evoked in a place serve as a perceptual, cognitive, and affective response to any environmental and associated stimuli. Emotions have a direct influence on our "being in place." Since the 1990s, discourse on the emotional significance that people develop toward a place has become critically important. Nevertheless, during my undergraduate years studying architecture and postgraduate studies in environmental psychology, I recall much confusion and criticism regarding the conceptualization of the emotional nexus between the self and place (Giuliani and Feldman, 1993; Lewicka, 2011).

In the existing literature, the emotional connection between one's self and a place has generally been called "bonding," and centered around the understanding of the emotional intensity and psychological processes involved in making meaning of/with place (Williams, 2014). One of the earliest conceptualizations of this affective bond between the self and place came from Tuan (1974). "Topophilia", theorized the bonding with well-known places through the generation of warm feelings. Yet Tuan's theory did not tell us much about possible attachment to unknown or prohibited geographies. Other scholarships has been referred to "place identity" (Proshansky et al., 1983), "sense of place" (Stedman, 2002), and "place attachment" (Altman and Low, 1992). Although the main discourse of these concepts focuses on the positive affect and experience of a place, few studies have mentioned the "shadow side" (Chawla, 1992) of such emotional connections where a place does not always evoke positive emotions.

The inspiring studies of geographers (Tuan, 1974; Relph, 1976) in the 1970s, which introduced the phenomenological paradigm concerning the self and place, led to the conceptual development of "place identity" in environmental psychology in the 1980s. This term has been widely used since to describe the process of inhabitants' symbolic meanings of a place and how the place becomes a part of one's identity. At the concept's core is people's identification with a place generated through feelings and ideas, as well as memories (Proshansky et al., 1983). In other words, it refers to the process of how a place can become an extension of one's identity. Conversely, this concept of attachment has been criticized for its inability to define one's emotional connection with a place. Earlier studies revealed that although people develop emotional bonds with places, they might not necessarily identify with them (Hernandez et al., 2007). In previous research that discussed place attachment patterns of Turkish Cypriot refugees settled in abandoned Greek Cypriot houses in Kato Varosha, I showed that although younger generations living there were more attached to their environment than the older generations, they did not wish to be identified with this attachment. In other words, the current environment no longer supported their identity (Boğaç, 2009). Therefore, place bonding 
is the basis for place identity, rather than being one aspect of the concept (Dixon and Durrheim, 2000).

The term "sense of place" is commonly used in the literature of many fields including geography, environmental psychology, architecture, sociology, anthropology, phenomenology, urban design, and human ecology. As a concept, it combines emotions and memories of and experiences in a place. Tuan (1977) seminal study discussed people's processes of sense-making regarding space, in which space becomes place through one's application of emotions and experiences to it. The concept of "sense of place" then, suggests that meaning is generated through one's interaction with a specific place, which includes emotional embodiment, cognitions, behaviors and identity (Stedman, 2002). In this sense, "sense of place" can also be defined as a more ambitious and comprehensive concept with many levels (such as rootedness, alienation, and placelessness) that need to be examined.

The concept of place attachment, on the other hand, was introduced during the 1990s (Altman and Low, 1992) and includes the processes involved in both the formation and maintenance of an emotional connection (nexus) and the feeling (bond) to place by people (Giuliani, 2003). In the last decade, studies that concentrated more on emotions, which seeks to understand our nexus with the environment, are refereed as place attachment research more than the sense of place or place identity studies (Scannell and Gifford, 2010; Lewicka, 2011; Hernandez et al., 2014). For example, Hernandez et al. (2014, pp. 125-126) grouped the main conceptual frameworks in the literature to study emotional intensity to a place under "place attachment". Scannell and Gifford (2010), on the other hand, offered a three-dimensional framework to clarify and structure former concepts and terms related to place attachment. Therefore, I want to adapt the concept of place attachment to this research as an operational construct to investigate emotional intensity and an affective bond toward an environment that is the locus of attachment. I also believe that Low and Altman's(1992) question, regarding people's attachment to not-so-well-known places, highlights the possible interest of place attachment studies in prohibited geographies, which matches the purpose of this research.

\section{Reproducing a prohibited place}

Exploring emotions toward a place developed over more than 30 years is not an easy task. Moreover, as mentioned earlier, Varosha is officially a "prohibited area," which makes it an exceptionally sensitive case to study from a political standpoint. Due to this level of sensitivity, not many people are eager to share their experiences, and those who are, generally tend to hold back information, as a precaution. Even taking photos of Varosha is illegal. For these reasons, this research is based on a personal ethnographic narrative ${ }^{1}$ within a very specific cultural context.

In this paper, I want my self-introspection to reflect my experience of Varosha, which is a world where everything is beyond the possibility of touch, and yet, can also engender involuntary and very intense

\footnotetext{
${ }^{1}$ Ethnography as a qualitative research method dates back to the early 20th century with the work of anthropologists. Ethnographic approaches seek to explore the lives of others by participating in research and describing an insider's point of view that is acknowledged and valued more in the 21 st century. Denzin and Lincoln (1994) identify five historical movements for qualitative research: (i) The traditional (1900-1950), (ii) The modernist or golden age (1950-1970), (iii) The blurred genres (1970-1986), (iv) The crisis of representation (1986-1990), and (v) The postmodern or present (1990-). Autoethnography has been referred to as part of the fifth movement where a new sensibility toward participatory research and writing emerged. Although there is an inescapable "biographical dimension" in ethnographic research (Coffey, 2002), the main difference is generally referred to as the researcher's position as an "insider." Ellis and Bochner (2000, p. 739) define the method as a genre of writing that "displays multiple layers of consciousness, connecting the personal to the cultural."
}

emotional encounters. I call my experience involuntary since neither I nor the other citizens of the city are the decision makers regarding the many prohibitions related to the place. My home and my life revolved around Varosha where a wide range of intense emotions were and are evoked. These are vividly captured between the lines of the city's inhabited part, where daily activities continue, and the prohibited place, where time stands still.

Bochner (1994) stressed that there is a growing interest among social scientists to question research findings that rely solely on data, and that data can be extended with stories rather than just theories through a value-centered experience. I believe that place attachment studies do not exhibit enough sensitivity to human emotions, especially when they rely heavily on quantitative research methods. According to Pavlenko (2007), autoethnography allows us to gain deep knowledge of and insights into an individual's first-hand experience, thereby providing rich data for studies. With this in mind, autoethnography is one of the methods that acknowledge emotions rather than hide them (Ellis et al., 2011) while trying to help eliminate any missing data that participants could withhold due to personal safety reasons.

For Sartre (1981), pp. ix-x, the uniqueness of one person can bring remarkable insight into research. Therefore, I strongly believe that my first-hand experience can provide deep insights on place attachment and sense of place at Varosha. Since childhood, I have used art and science $^{2}$ to describe my narrative of Varosha and kept journals since the age of six, albeit irregularly. The entries thereon are a result of my musings, which reflect as fragmented queries portraying my domains of interest and the events happening around me. In other words, they are products of my embedded memory landscape of Famagusta representing more than 30 years. As a source for this research, I have used these chronicles to help prompt my recall of the past and personal stories pertaining to Varosha.

In the next section, I present these personal experiences based on the flow of important life events starting from early childhood. From a total 15 journals, I have tried to highlight important vignettes related to Varosha. To reflect my interaction with the place, I have tried to describe my every emotion toward it-for this, I have used evocative autoethnography. Autoethnography as defined by Bochner and Ellis (2016), involves the narrative presentation of the lived experiences like stories and/or biographies that elicit emotional responses, to enable the reader to see himself/herself as the researcher. As a result, the following section has its own format of a narrative. Due to its nature of being a "self-claimed phenomena," as defined by Ellis et al. (2011), everything that was reproduced through this recall can be called an "epiphany" of the place.

\section{My story of Varosha}

\subsection{Confrontation with a prohibited geography: early and middle childhood (1980-1990)}

Before writing this section, I tried to remember the first time I noticed this prohibited geography. I realized that until the age of six, Varosha did not have any meaning or association for me; the ongoing conflict held no significance for me at the time as my level of sociopolitical awareness was beyond my age-related cognitive processing abilities. After the internal conflicts and moving from one place to another, in 1974, my father's family was finally given an abandoned house in Kato Varosha. From what I have gleaned from the stories that were told to me, my father's family moved four times, to different houses, before settling in Kato Varosha. This house was a sanctuary and permanent residence for me but a temporary shelter for my grandmother. The traumatic experience of being forced to leave her primary

\footnotetext{
${ }^{2}$ I wrote short essays and stories, drew many sketches, and conducted research and implemented projects on Varosha.
} 
residence- the place she identified as home-did not stop her from dreaming about returning there someday. She knew that we had settled in the house of people who, too, had cherished it as their home and its memory, and hoped to return to it one day. She referred to them as the "real owners" and saved all their personal belongings, living in that house as a guest until her last breath. She passed away before the borders between the north and south were opened for crossing in 2003, unable to see or return to her home.

Discovering the personal belongings of "strangers" in my grandmother's house was the turning point of my life. I was six when I asked her who all those photos, glasses, books, and journals belonged to; she replied "the real owners of this house" and added "who will come back to live in their house when we return to our real home in Larnaca." I still remember that I perceived this statement to be the most dangerous, threatening, and painful thing I had ever heard in my life. Despite having a contented, safe, and peaceful childhood, hearing ideas and stories of possibly having our happy home taken away from us was very disturbing for me-I remember having many questions that needed answers. Some of these questions were: Who were the real owners of our home? Why would we leave our home someday and live in Larnaca? When would the real owners of our home return? Why did those people leave their home in the first place? Why was Varosha surrounded by barbed wire fences and declared prohibited? Continuous questioning of the reasons for the fragmentation of the physical environment increased my curiosity about Varosha. My strange but happy life on the periphery of the prohibited place was not limited to my grandmother's house. The house my parents settled in Kato Varosha directly faced the fenced-off sector and was located next to the border.

Famagusta is surrounded by the Turkish Armed Forces (Varosha), British Forces (U.K. Sovereign Base Area), and the United Nations (UN Buffer Zone). There are two border crossings to the south-one opened in 2003 (U.K. Sovereign Base Area) and the other in 2018. While I was growing up, no possibilities or opportunities existed for travelling to the island's southern part. In Fig. 1, I have tried to show my childhood domains, all of which were close to the Varosha border.

\subsection{Expounding an uncanny geography: adolescence (1991-1997)}

Varosha has been a prohibited place since before my time, and my interactions with it mostly occurred along the border, as indicated by many abstractions. I remember some conversations with my brother while observing the abandoned houses and seeing their moth-eaten curtains year after year, wondering who could have possibly lived in this place before the island's division. Our father talked about the vibrant years, telling stories of the water games, disco nights, high tourist flow, and the famous Orange Festival. He had even bought our mother's engagement dress in Varosha right before the division.

"Narrative linkage through story telling" is one of the six ways people establish association with a place (Low, 1992: p.166). They create and reflect place meanings through storytelling (Williams, 2014), as Tuan (1980, p. 6) rightly said, "City people are constantly 'making' and 'unmaking' places by talking about them." It is clear that Varosha has come alive through stories, whereas in reality, it was left to deteriorate. At that time, there were no electronic or print resources on Varosha; hence, as children, we had to use our creative imaginations, which compelled us to envision a utopian past. Idealization, formerly defined as one of the four forms of "childhood place attachment" (Chawla, 1992), is based on abstraction rather than an actual experience. At the beginning of my adolescence, because I was curious to know more about the prohibited place, I constructed an imaginary geography of Varosha, a first step in developing a bond with it. When I was given more independence to discover the place, like playing or walk along the border, based on my bodily sensations vis-à-vis the emotions evoked, I realized that some of my observations were based on fear. I noted in my journal covered with Mickey Mouse stickers:
My brother was screaming "There were clothes in the wardrobe of that abandoned house. I saw it when the soldiers opened it up! I was at the balcony. I saw it!" (April 3, 1992)

I remember that day so well. I was on the balcony of our house with my brother, trying to fly a kite. When I went inside for a second to find more string, my brother screamed, bringing me running back. The soldiers were looking for something in an abandoned house opposite ours. We could see clothes sprawled on a bed through the windows the soldiers had opened. When they saw us on the balcony, I do not know why but we ran inside in panic, leaving the string of our kite-that day, our kite joined Varosha's other trapped treasures. We were petrified, and one possible reason for this fear may have been my earlier childish attempt to sneak into the prohibited place, which had been a scarring experience after being caught by the soldiers, despite them causing me no harm and safely delivering me home. This event had happened when I was 10 or 11, transforming my curiosity into fear.

During my adolescent years, I was allowed to ride my bicycle from my parents' house to my grandmother's house along the border, a route that was exciting and appalling in equal measure. While trying to recall this route (Fig. 2), I remembered a vague image of a library with many books scattered around somewhere over the border. I had always wished to save some of those books. I also remembered the day I found a bullet in the wall of a house on the border. I was probably 12 then, and at first, this was a thrilling experience, like discovering a magical object. However, soon after, I was filled with remorse, and I removed the bullet; since then, I have kept it as a keepsake in a small box. My cognitive representation of this route also contains the image of giant plants that began as tiny saplings in small pots on the balconies of the abandoned buildings. I also remembered a cactus that had half of its arms extending into the other side over the border-this signifies the life that wants to grow beyond the fences.

All of these vivid portrayals of the past, which were frightening most of the time, were overshadowed by an uncanny feeling, which I depicted in a short story "Are angels sad?" ${ }^{3}$ My notes for this story can be found on many pages of my journals. I wrote it based on my observations of Varosha, made from my bedroom window, which gave me in-depth views of the interiors of many abandoned houses. The story was about an internal dialogue with a woman/ghost who was trapped in an abandoned house. Ellis (2004, pp. 194-196) said, "there is nothing more theoretical or analytical than a good story" since "when people tell their stories, they employ analytic techniques to interpret their world." Indeed, this story was a fictional expression of my cultural self-discovery of the place as an outsider and my first interpretation of the possible feelings of an insider, represented by the ghost. The story began with how I first noticed this ghost over the border, continued with my questioning as to why she was there, and ended with my discovery that it was, in fact, me representing her decomposing flesh even as I was living across the border. I have always felt that once you witness the decomposition of a place, you perceive it as a grave that traps your own flesh, and you feel like you are dying with it:

We see the old ghosts of the starry nights that were borrowed from our friends a long time ago. They come back to life from the old diaries that are the followers of old times. But when the wind blows, they fall from the pages one by one with an untimely spring breeze ...

We both know now that she and I had a common life once. And I know the reason for her stay. And she knows the reason for my odd loneliness. My beautiful angel, who cries over my grave after my every death! No matter how many years have passed, you always find me! Did I take a lot from you since you are still waiting? Even though I wrote so many stories

\footnotetext{
${ }^{3}$ My published and award-winning short story in Turkish: Boğaç, C. (1998). Melekler mutsuz mudur? (Are angels sad?). International Turkish Language and Translation Magazine: Turnalar, 1, 74-75.
} 


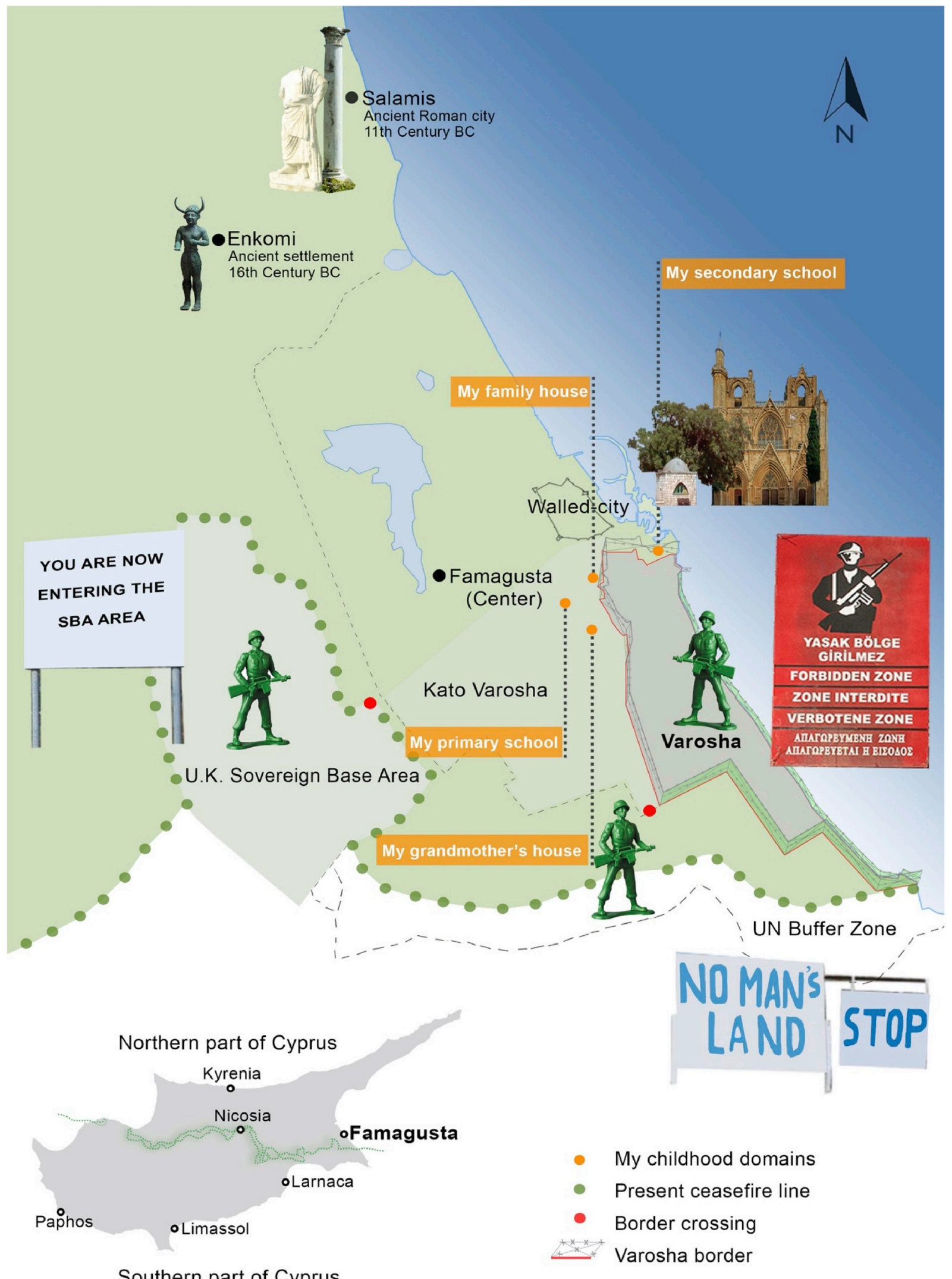

Fig. 1. Map of Famagusta (Illustrations by me, 2019). 


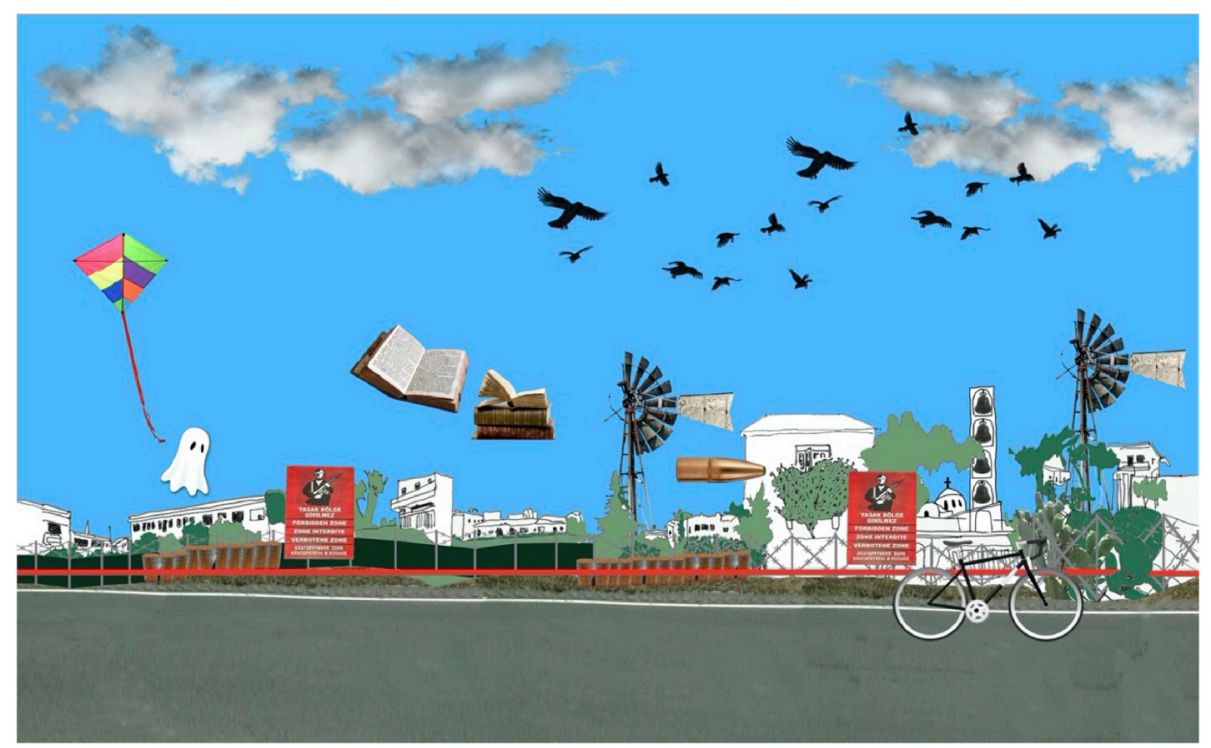

Fig. 2. Cognitive map of Varosha border (From my parents' house to my grandmother's house, Drawing and illustrations by me, 2019).

about you, isn't it so strange that we have not met yet? The ghosts of my childhood, who are waving at me every night from your window; hey look, everything still remains the same in a frozen time and in a frozen place! (March 8, 1997)

The metaphorical expressions in the story are clearly centered on the feelings of witnessing the traces of life that was once there, which continue to disappear season after season. My reciprocal relationship with the place was projected as the stay of the woman/ghost in the story (who is later called an angel) and my loneliness due to living next to a place referred to as a "ghost town." The line that we had not met was to convey that I had not met any Varosha refugees. The appellation of "angel" given to the woman/ghost was a proclamation of the innocence of those who were forced to leave their homes. At first glance, the story appears to be a fictional tale of the ghostly memories of the displaced revenant, as defined by Wylie (2007) in his inspiring study on spectral geographies. As hauntology expresses the return of the revenant and denotes the place of return (Derrida, 1994), in the story, the woman/ghost was portrayed as a revenant trapped in Varosha, as my neighbor. By referring to W. Benjamin and W. G. Sebald's works, Wylie (2007) highlighted how places were pursued by past traumas and catastrophes, and represented as transfixed and spellbound. Varosha is similarly manifested in this story. Wylie (2007) defined the haunting effect, "always found by the woman/ghost" in my story, as a "prerequisite" to the place. Conversely, in my story the haunting effect expresses the psychological processes developed for an uncertain environment.

It is clear that the main theme of the story is a symbolic confrontation between the past life of Varosha and mine on the periphery of this frozen spectacle rather than a spectral fantasy. In the story, Varosha is described as a familiar and an unfamiliar place, in other words, "uncanny" as defined by Freud. According to Freud (1955), p. 220 , "the uncanny is that class of the frightening which leads back to what is known of old and long familiar." Indeed, Varosha has been the real and unreal or familiar and unfamiliar geography, maintaining the threshold of a hovering presence that is there and yet is not. It is thus not a coincidence that fear was one of the initial emotions the place evoked in me, since it was forbidden, guarded, and unknown. As part of its daily routines, the place has always encountered the foreign within the familiar. All remnants of its past life, such as abandoned structures and belongings that were visible beyond the border, have curated this place's uncanniness. It has been a concealed geography causing a division in people's minds, as well as in the continuity of the city's landscape and its history. Perhaps this division is why it has always been referred to as a "ghost town," since such uncanny experiences are generally associated with ghostly figures. However, in my story, I could not define the place as ghostly. I essentially pictured Varosha as an uncanny geography, which is similar to the feeling itself. I believe it presents itself as an uncanny geography not only for me but also for all its citizens, especially after its dramatic becoming and transformation over the years. It represents the place's paradoxical and reciprocal flow between familiar and unfamiliar.

\subsection{Affection for the uncanny geography: early adulthood (1998-2014)}

Varosha's environmental attributes transformed the place for me over time. In 1999, I described its physical transformation, as a result of being a human-free environment for over 25 years, in my journal thus:

I am standing on the roof of our house. It is no longer easy to see where all those streets are leading to. Half of my city is transforming itself into something we cannot know. It really looks like a science fiction movie. (May 5, 1998)

This description might bring Gieryn's (2000, p. 481) place-sensitive sociology to mind, in that is suggests that people can develop strong attachments to places with easily defined edges. However, unclear physical attributes and boundaries were not responsible for my attachment to Varosha. As Lim and Barton (2010) noted, I made more detailed observations of the place while making meaning of it even though it was not completely visible to me:

Another evening, I am walking next to the border: These streets are the ruins of abundantly wasted hopes. Not one, but millions of shadows of suicide fall on to the doors. The doors have no lock or slides; yet they cannot be opened easily. Since there is no heavy traffic on those streets, you may even catch your own funeral. (April 01, 2000)

These notes were my reproduction of the feelings of the abandoned neighborhood's former residents. Varosha was a well-protected place even though most of the house doors were broken. It was deathly quiet, with not even an animal to be seen prowling its empty streets. I see that as much as Varosha transformed itself by being a human-free environment, with nature taking over, the use of metaphor to describe it in my journals is apparent. These metaphors also reflect my hidden feelings toward Varosha. The feeling of being defeated, which was not easy to describe, is expressed in my journal thus: 


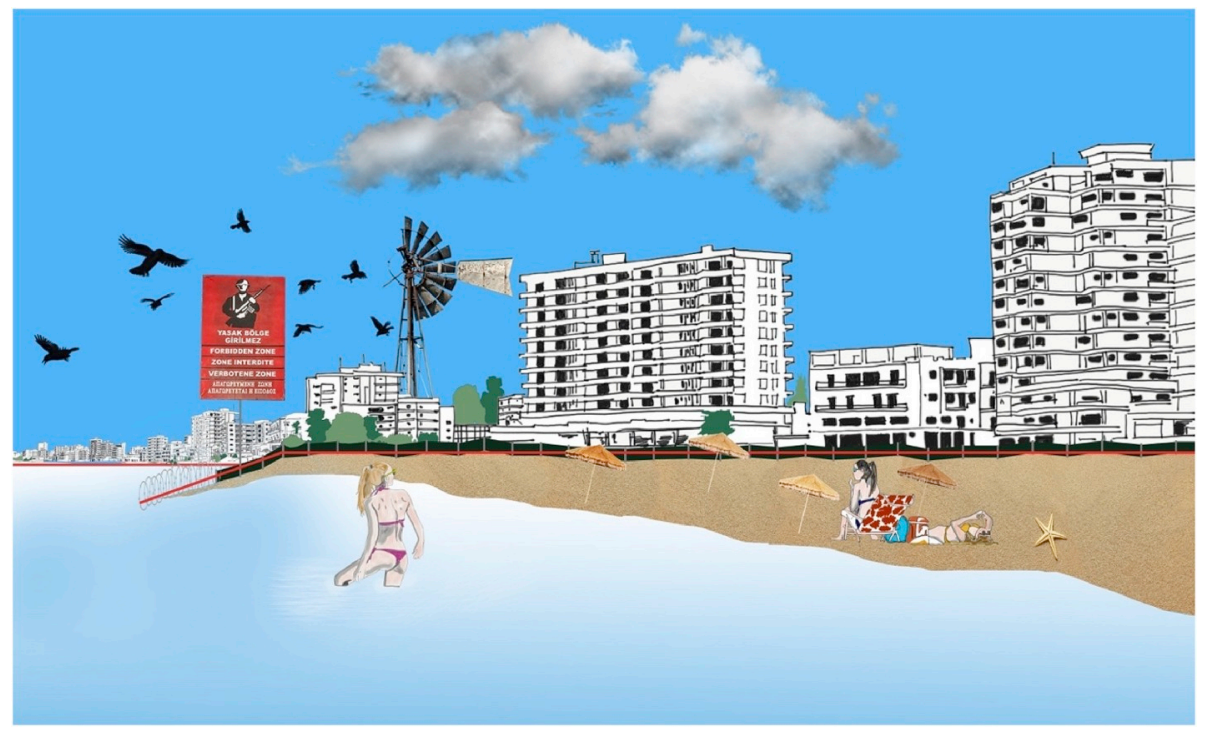

Fig. 3. Iconic image of "ghost town" Varosha (Drawing and illustrations by me, 2018).

If I want to walk and reach the end of this shore, even my footprint will not stay on the sand. Please do not bless our defeat at the coast of fear! My heart sinks deeper and deeper. Even the loneliness has thousands of different forms. What hurts me most is to live facing those houses that stand as confused women who have lost their memory and whose hearts cry at the top of a wind mill. (April 01, 2000)

I have tried to embody the iconic image of this shore, where my footprint will never stay, portrayed in my writing as an illustration in Fig. 3. There are various photographic images of this shore on social media although photography is prohibited. A small portion of the beach, surrounded by abandoned hotel buildings separated by a green border fence, is allotted for public use. A small guard house is located on the border with a sign depicting a soldier holding a gun and declaring the rest of the shore, which encompasses $6 \mathrm{~km}$ of the beach, as "forbidden." At this beach I learned to swim under the shadow of the empty and partially bombed hotel buildings that stand as decaying monuments of the conflict. Varosha has other names, given by the citizens, such as "City of Wind Mills" as most of these wind mills are still visible from across the border, as are the birds inhabiting an empty fivestar hotel. Every year, many curious locals and tourists visit this golden beach and add another picturesque portrait of "Greetings from the Ghost Town" to their memories.

While trying to express in my journal how I felt, the situation in Varosha disturbed my conscience, and acted to help me realize the injustice of everything that had happened to this place. When I was younger, Varosha was only a "prohibited place" that was unfamiliar. Over time, my internalization of the traces of its past lives revealed "empathy." Since early adulthood, I could not stop thinking about those innocent people who were forced to leave and their souls that are trapped beyond the barbed wire. In his inspiring book, Relph (1976) formulated the strongest form of place experience as "existential insideness" and defined its opposite, "existential outsideness," as alienation from a place. Through several modes of his identification of insideness and outsideness, Relph described "empathetic insideness" as when a person as an outsider develops an emotional and empathic involvement with and interest in a place. This conceptualization seems to be the most adequate description of my emotional connection with Varosha. After an intense and diverse emotional involvement, the feeling of "empathy" strengthens my ties to this place. Since this is a new form of attachment to an uncanny geography that is absent from the existing literature, I call it "empathic place attachment" based on Relph's (1976) conceptualization.
This empathic place attachment made me want to develop physical contact with the place, which was not and is not possible due to the restrictions. In my journal, an abandoned church that was almost attached to the border is described thus:

That building was standing halfway on the route from my parents' house to my grandmother's. It was located on top of a high perch. Its bells were still in their place. I always wanted to ring those bells with all my power and wake up every sleeping creature in Varosha. (February 29, 2008)

Every time I rode my bicycle or walked along the border, my shadow would fall inside Varosha. If someone asked me what my most vivid memory from those days was, I would say it was each building's or forgotten object's call for help every time I passed them, like that of the church.

\section{Concluding remarks}

In this paper, I have tried to evaluate manifestation of an emotional nexus between the self and a prohibited place, which is largely unexplored in the existing literature. Varosha is that place-involuntarily abandoned by its citizens, declared a prohibited area, and sealed by the army. As a part of the development of this emotional nexus and aiding in the creation of that bond, I constructed an imaginary geography based on the stories I had heard from my family, who had experienced the place in the past. Year after year, this place haunted me, not least because I experienced the loss or displacement from it like its former citizens, but because I was prohibited from being "placed" in it. I experienced this place along the border as an uncertain environment filled with a wide range of conflicting emotions. My evolving emotions categorized it as an "uncanny geography."

To reproduce my emotional encounters with Varosha and develop an analysis based on them, I used evocative autoethnography. I wrote an epiphany of the place based on my journal entries, where I talked about my sensorial experiences and stories of this place, such as how I observed its physical transformation and touched the shells of abandoned structures along the border. Using this autoethnographic analysis, not only did I reproduce my past emotional-spatial experiences of the place, but I also created illustrations reflecting and representing my discussions. I believe that future research that explores data from personal journals related to a specific location could provide more insights into the processes involved in place attachment. Such analyses may help ascertain reported changes over time, which may contribute to the longitudinal research as well. 
My main motivation for this research was to provide a new assessment of emotions evoked toward a prohibited place, which are considered a rare fabric of our distinctive personal geographies. My analysis portrayed that although my first embodied emotional response to Varosha involved fear, over the years, it has transformed into a love for this place-present in almost every childhood photo was Varosha, like a surreal curtain hiding unexpected landscapes behind it. Despite the physical restrictions, I had various vivid experiences that were formative, especially in my childhood. I chose to name my personal connection with this place as "empathic place attachment," drawing from conceptualizations of an emotional nexus within a geography as developed from Relph's (1976) formulation of "empathetic insideness." I called my attachment process "empathic" because of the whole range of emotional states I had been through over the past 30 years. This relationship may be one of the most complex a person could develop regarding any geography, and I believe that such a new form of attachment is open to development.

As a final remark, I believe that the revival of the place, with its reintegration into Famagusta, will promote peaceful coexistence among all of its citizens, which is essential. This process carries great significance not only for its former inhabitants (Greek Cypriots) but also to heal the memories of the Turkish Cypriots, who experienced the dramatic existence of Varosha and developed an attachment to this uncanny geography.

When you return home, please do not break the silk braid of my heart which wraps this land. Those barbered wires could not suppress the revolt of our city. It has waited long enough to be united with its other half ...

(October 06, 2011)

\section{Acknowledgements}

I like to thank Prof. Dr. Yonca Hürol for reviewing this paper and for her constructive comments during the earlier drafts of the study. Thanks also go to the anonymous reviewers and Danielle Drozdzewski for their helpful comments and insights.

\section{References}

Altman, I., Low, S.M., 1992. Place Attachment (XII). Springer US, New York. Boğaç, C., 2009. Place attachment in a foreign settlement. J. Environ. Psychol. 29, 267-278.

Bochner, A.P., Ellis, C., 2016. Evocative Autoethnography: Writing Lives and Telling Stories. Routledge, New York.

Bochner, A.P., 1994. Perspectives on inquiry II: theories and stories. In: Knapp, Mark L., Miller, Gerald R. (Eds.), Handbook of Interpersonal Communication. Sage, Thousand Oaks, CA, pp. 21-41.

Bondi, L., 2005. Making connections and thinking through emotions: between geography and psychotherapy. Trans. Inst. Br. Geogr. 30, 433-448.

Brown, B.B., 1987. Territoriality. In: Stokols, D., Altman, I. (Eds.), Handbook of Environmental Psychology. Wiley, New York.

Brown, B.B., Perkins, D.D., 1992. Disruptions in place attachment. In: Altman, I., Low, S.M. (Eds.), Place Attachment (XII). Springer US, New York, pp. 279-301.

Casey, E.S., 1997. The Fate of Place: A Philosophical History. University of California Press, Berkeley, CA.

Casey, E.S., 1993. Getting Back into Place: toward a Renewed Understanding of the Place World. Indiana University Press, Blomington.

Chawla, L., 1992. Childhood place attachments. In: Altman, I., Low, S.M. (Eds.), Place Attachment (XII). Springer US, New York, pp. 63-84.

Coffey, A., 2002. Ethnography and self: reflections and representations. In: May, T. (Ed.), Qualitative Research in Practice. Sage, London, pp. 313-331.
Cooper Marcus, C., 1992. Environmental memories. In: Altman, I., Low, S.M. (Eds.), Place Attachment (Vol XII). Springer US, New York, pp. 87-112.

Denzin, N.K., Lincoln, Y.S., 1994. Introduction: entering the field of qualitative research. In: Denzin, N.K., Lincoln, Y.S. (Eds.), Handbook of Qualitative Research. Sage, Thousand Oaks, CA, pp. 1-17.

Derrida, J., 1994. Specters of Marx, the State of the Debt, the Work of Mourning and the New International. Routledge, New York and London Translated from the French by Peggy Kamuf.

Dixon, J., Durrheim, K., 2000. Displacing place-identity: a discursive approach to locating self and other. Br. J. Soc. Psychol. 39 (1), 27-44.

Ellis, C., 2004. The Ethnographic I: A Methodological Novel about Autoethnography. AltaMira Press, Walnut Creek, California.

Ellis, C., Adams, T.E., Bochner, A.P., 2011. Autoethnography: an overview. Forum: Qualitative social Research Sozialforschung 12 (1).

Ellis, C., Bochner, A.P., 2000. Autoethnography, personal narrative, reflexivity: researcher as subject. In: Denzin, N.K., Lincoln, Y.S. (Eds.), Handbook of Qualitative Research. Sage, London, pp. 733-768.

Freud, S., 1955. The uncanny. In: Strachey, J. (Ed.), Standard Edition of the Complete Psychological Works of Sigmund Freud. Hogarth Press, London, pp. 219-253 Volume XVII (1917-1919): An Infantile Neurosis and Other Works.

Gieryn, T.F., 2000. A space for place in sociology. Annu. Rev. Sociol. 26, 463-496.

Giuliani, M.V., 2003. Theory of attachment and place attachment. In: Bonnes, M., Lee, T. Bonaiuto, M. (Eds.), Psychological Theories for Environmental Issues. Ashgate, Aldershot, pp. 137-170.

Giuliani, M.V., Feldman, R., 1993. Place attachment in a developmental and cultural context. J. Environ. Psychol. 13, 267-274.

Gustafson, P., 2001. Meanings of place: everyday experience and theoretical conceptualizations. J. Environ. Psychol. 21, 5-16.

Heidegger, M., 1962. Being and Time. Harper and Row, New York.

Hernandez, B., Hidalgo, M.C., Ruiz, C., 2014. Theoretical and methodological aspects of research on place attachment. In: Manzo, L.C., Devine-Wright, P. (Eds.), Place Attachment, Advances in Theory, Methods and Applications. Routledge, New York, pp. $125-138$.

Hernandez, B., Hidalgo, M.C., Salazar-Laplace, M.E., Hess, S., 2007. Place attachment and place identity in natives and non-natives. J. Environ. Psychol. 27, 310-319.

Lewicka, M., 2011. Place attachment: how far have we come in the last 40 years? J. Environ. Psychol. 31, 207-230.

Lim, M., Barton, A.C., 2010. Exploring insideness in urban children's sense of place. J. Environ. Psychol. 30, 328-337.

Low, S.M., 1992. Symbolic Ties that bind: place attachment in the plaza. In: Altman, I., Low, S.M. (Eds.), Place Attachment (Vol XII). Springer US, New York, pp. 165-185.

Low, S.M., Altman, I., 1992. Place attachment: a conceptual inquiry. In: Altman, I., Low, S.M. (Eds.), Place Attachment (Vol XII). Springer US, New York, pp. 1-12.

Pavlenko, A., 2007. Autobiographic narratives as data in applied linguistics. Appl. Linguist. 28, 63-188.

Proshansky, H.M., Fabian, A.K., Kaminoff, R., 1983. Place identity: physical world socialization of the self. J. Environ. Psychol. 3, 57-83.

Relph, E., 1976. Place and Placelesness. Pion, London.

Sartre, J.P., 1981. The Family Idiot: Gustave Flaubert. University of Chicago Press, Chicago Translated by Carol Cosman, 1.

Scannell, L., Gifford, R., 2014. Comparing theories of interpersonal and place attachment. In: Manzo, L.C., Devine-Wright, P. (Eds.), Place Attachment, Advances in Theory, Methods and Applications. Routledge, New York, pp. 23-36.

Scannell, L., Gifford, R., 2010. Defining place attachment: a tripartite organizing framework. J. Environ. Psychol. 30, 1-10.

Seamon, D., 2014. Attachment and phenomenology: the synergistic dynamism of place. In: Manzo, L.C., Devine-Wright, P. (Eds.), Place Attachment, Advances in Theory, Methods and Applications. Routledge, New York, pp. 11-22.

Stedman, R.C., 2002. Towards a social psychology of place: predicting behavior from place-based cognitions, attitudes, and identity. Environ. Behav. 34 (5), 405-425.

Tuan, Y.F., 1980. Rootedness versus sense of place. Landscape 24 (1), 3-8.

Tuan, Y.F., 1977. Space and Place: the Perspective of Experience. The University of Minnesota Press, Minnesota.

Tuan, Y.F., 1974. Topophilia. Columbia University Press, New York.

Von Wirth, T., Gret-Regamey, A., Monser, C., Stauffacher, M., 2016. Exploring the influence of perceived urban change on residents' place attachment. J. Environ. Psychol. 46, 67-82.

Williams, D.R., 2014. Beyond the commodity metaphor, revisited: some methodological reflections on place attachment research. In: Manzo, L.C., Devine-Wright, P. (Eds.), Place Attachment, Advances in Theory, Methods and Applications. Routledge, New York, pp. 89-99.

Wylie, J., 2007. The spectral geographies of W. G. Sebald, Cultural Geographies 14, $171-188$. 